RAD Conference Proceedings, vol. 3, pp. 106-110, 2018

ISSN 2466-4626 (online) | DOI: 10.21175/RadProc.2018.23

www.rad-proceedings.org

\title{
RADIOLOGICAL CHARACTERIZATION OF PORTUGUESE NATURAL MINERAL WATER
}

\author{
A.S. Silva ${ }^{1,2}$, M.L. Dinis ${ }^{1,2^{*}}$ \\ ${ }^{1}$ CERENA - Polo FEUP - Centre for Natural Resources and the Environment, \\ Faculty of Engineering, University of Porto, Porto, Portugal \\ ${ }^{2}$ PROA/LABIOMEP - Research Laboratory on Prevention of Occupational and Environmental Risks, \\ Faculty of Engineering, University of Porto, Porto, Portugal
}

\begin{abstract}
Natural mineral waters used in therapeutic treatments present diverse chemical composition which can include natural radionuclides, such as radon, increasing the risk of exposure to natural radiation for both workers and bathers. The purpose of the present study was to evaluate the radon concentration in natural mineral waters of 17 Portuguese thermal establishments. The evaluation was carried out between 2013 and 2015 in several places of each thermal establishment. An analysis of the compliance between the obtained values and the existing legal requirements for the different parameters concerning radon concentration in water was made. The results showed the presence of anomalous values both higher than the reference level and the action level. Approximately 50\% of the obtained results are higher than the reference level recommended by the EU, while $20 \%$ of the results exceeded the action level. These results may also imply high concentrations of indoor radon (and hence occupational exposure to radon), since the natural mineral water will be a continuous source of this radionuclide. The high values obtained in some cases are worrying and show the need for a more detailed and extensive study, both in space and time.
\end{abstract}

Key words: Exposure, radon, thermal establishments, water

\section{INTRODUCTION}

In Portugal, there is a long tradition of using natural mineral waters for medicinal purposes (thermalism) with recognized health benefits mostly due to the specific properties given by a diverse chemical composition and temperature. However, natural mineral waters may also contain significant amounts of natural radionuclides, such as radon, which will increase the risk of exposure to natural radiation both for workers and bathers.

Radon gas can appear dissolved in natural mineral water and may be released into indoor air. The release of radon into the environment occurs when it comes into contact with air, since the radon gas has very different solubility in these two media, and the partition coefficient is favorable to air. The estimation of radon transferred from water to air involves different factors such as the solubility of radon in water, the amount of water used in the dwelling, the volume of the dwelling, and the ventilation rate. The proportion of radon transferred from water to air will depend on the temperature and water salinity. The amount of waterborne radon escaping into the air is different throughout a dwelling but is higher in areas of active water use such as bathrooms and kitchens. The same will occur in thermal establishments: the indoor radon concentration will be higher in areas with water usage for therapeutic treatments, and in this case, it will also depend on the processing to which water goes through at the circuits and places of use [1], [2].

The relationship between the lung cancer risk and radon exposure is well known [3], [4], [5] - [19]. The evidence of this relationship comes from epidemiological studies with miners, especially from uranium mines, who are potentially exposed to high levels of radon, along with other chemicals, radioactive minerals and particulate matter [13] and recently from epidemiological studies of regions with high radon levels. This is the case of some studies conducted in the population from the USA, France and the United Kingdom [20].

The worldwide proportion of lung cancers due to indoor radon exposure is estimated to range between 3 and $15 \%$, depending on average radon concentration in the concerned country and calculation method [10, 11]. Nevertheless, until now the only certain situation and proven scientifically, results from the epidemiological studies.

Many countries under national legislation, as well as under international norms and recommendations, have defined an action level for radon. However, the action level must be adequately interpreted as this is not a boundary between safe and unsafe; it is rather a value that was set so that the risk of a typical person drinking such water is similar to the risk from breathing air which contains radon at a level of 200

\footnotetext{
*mldinis@,fe.up.pt
} 
A.S. Silva \& M.L. Dinis, Radon concentration in natural mineral water, RAD Conf. Proc., vol. 3, 2018, 106-110

$\mathrm{Bq} / \mathrm{m}^{3}$. This is the action level of radon concentration in the air, which means that with this radon level mitigation measures should be taken to reduce radon level in homes.

Other values for indoor radon concentration have been mentioned by reference organizations: the WHO recommends that radon level should be kept below $100 \mathrm{~Bq} / \mathrm{m}^{3}$ [11], the International Commission on Radiological Protection stated a value of $300 \mathrm{~Bq} / \mathrm{m}^{3}$ [6] which is the same as the value set by the EU Directive 2013/59/Euratom [21].

The European Directive 2013/51/Euratom, on requirements for the protection of public health, with respect to radioactive elements in water intended for human consumption provides a parametric value between $100 \mathrm{~Bq} / \mathrm{L}$ and $1000 \mathrm{~Bq} / \mathrm{L}$ for radon concentration (not applicable to natural mineral waters) [21]. Correction measures for radiological protection reasons are considered justified where radon concentrations exceed $1000 \mathrm{~Bq} / \mathrm{L}$ [21]. The World Health Organization set the guidance level to $100 \mathrm{~Bq} / \mathrm{L}$ in the third edition of the WHO drinking water guidelines [9]. On the other hand, the Portuguese legislation Dec-Lei 23/2016, which establishes the requirements for the protection of the health of the general public with regard to radioactive substances present in water intended for human consumption, states that a parametric value for radon concentration should be set at $500 \mathrm{~Bq} / \mathrm{L}$ and where the radon concentration exceeds $1000 \mathrm{~Bq} / \mathrm{L}$, measures are warranted.

The United States set a Maximum Contaminant Level for radon in drinking water from private water supplies of $150 \mathrm{~Bq} / \mathrm{L}$, and although the EU recommends an action level of $1000 \mathrm{~Bq} / \mathrm{L}$, no reference value has been established yet as a threshold for the concentration of radon in mineral waters, as it is assumed that mineral waters are not consumed on a regular basis.

The objective of this study was to evaluate the radon concentration in natural mineral waters of 17 Portuguese thermal establishments and verify the compliance of the results with the different parameters for radon concentration in water from legal requirements. The study was developed between 2013 and 2015.

\section{MATERIALS AND METHODS}

The evaluation of radon concentration in thermal mineral waters was carried out in several places (inhalation therapy room - ORL, buvete, thermal pool, spring and vichy shower) of each one of the selected thermal establishment (TE) (Table 1).

Samples of water $(10 \mathrm{ml})$ were collected with a syringe at each water point and carefully poured into $20 \mathrm{ml}$ volume glass vials where previously $10 \mathrm{ml}$ of immiscible scintillation cocktail was added (Betaplate, Perkin-Elmer ( )). All measures were taken to prevent gas leakage during transport as bottles with a sealed opening and safety mechanisms were used.
Table 1. Thermal establishments participating in the study

\begin{tabular}{|c|c|c|}
\hline $\begin{array}{l}\text { Thermal } \\
\text { Establishment }\end{array}$ & District & County \\
\hline Caldas da Felgueira & Viseu & Nelas \\
\hline Caldas de Manteigas & Guarda & Manteigas \\
\hline Caldas da Rainha & Leiria & $\begin{array}{l}\text { Caldas da } \\
\text { Rainha }\end{array}$ \\
\hline Caldelas & Braga & Amares \\
\hline Caldas da Saúde & Porto & Santo Tirso \\
\hline Alcafache & Viseu & Viseu \\
\hline Taipas & Braga & Guimarães \\
\hline Cró & Guarda & Sabugal \\
\hline Entre-os-Rios & Porto & Penafiel \\
\hline Longroiva & Guarda & Meda \\
\hline Luso & Aveiro & Mealhada \\
\hline Moimenta & Braga & Terras do Bouro \\
\hline Monção & $\begin{array}{l}\text { Viana do } \\
\text { Castelo }\end{array}$ & Monção \\
\hline Sangemil & Viseu & Tondela \\
\hline S. Lourenço & Bragança & $\begin{array}{l}\text { Carrazeda de } \\
\text { Ansiães }\end{array}$ \\
\hline S. Pedro Sul & Viseu & S. Pedro do Sul \\
\hline Unhais Serra & $\begin{array}{l}\text { Castelo } \\
\text { Branco }\end{array}$ & Covilhã \\
\hline
\end{tabular}

The activity of the radionuclides present in the collected water samples was measured by means of Liquid Scintillation Counting (LSC) technique using an ultra-low level spectrometer (Quantulus 1220) in the Laboratory of Natural Radioactivity of the University of Coimbra. This is the standard laboratory method to quantify the radioactivity of low energy radioisotopes, mostly beta-emitting and alphaemitting isotopes. The sensitive LSC detection method requires specific cocktails to absorb the energy into detectable light pulses.

Radon gas measurements were performed using the double-phase method [22]. The uncertainties depend on the activity but, in general, were less than $15 \%$ over the measurement range.

For a more detailed description of the LSC techniques see Gonçalves and Pereira, 2007 [23]. The efficiency of the method was evaluated by measuring several standard solutions and by participating in inter-comparison exercises.

\section{RESULTS AND DISCUSSION}

The majority of the thermal establishments considered for radon measurements in natural mineral water are located in regions formed mainly by granite substrate, in the areas of fractures that are associated to fault zones (Figure 1). 


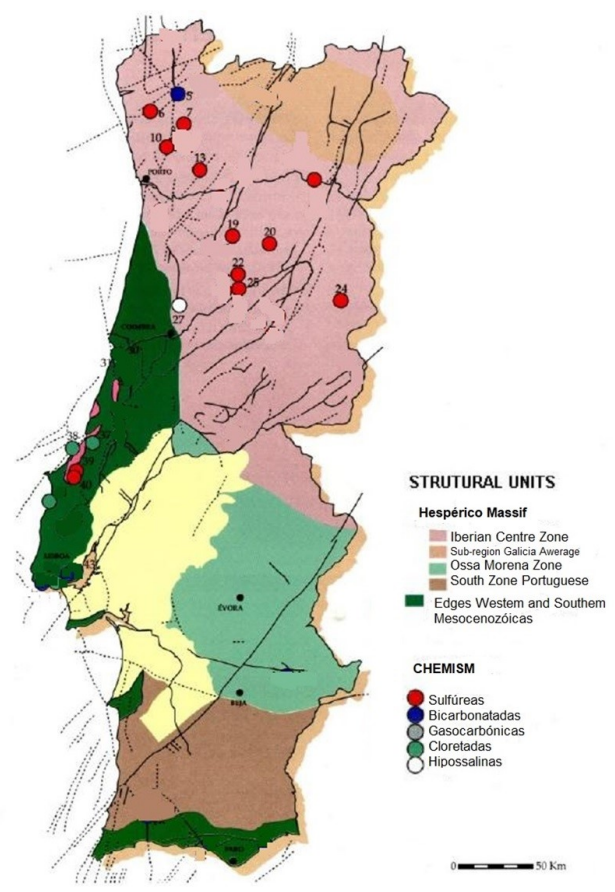

Figure 1. Location of the thermal establishments in mainland Portugal and its relationship with the large structural units

\subsection{Natural mineral waters}

The natural mineral waters under study are classified according to their chemical composition as mainly alkaline, sulfur, bicarbonate-sodium whereas some are also classified as radioactive to strongly radioactive [19].

Thermal techniques for therapeutic purposes comprise internal or external application techniques. Internal administration techniques take benefit from the chemical-physical composition of the mineral natural water and include: i) oral ingestion of water; ii) injection of natural mineral water (clyster) and iii) administration of water by colorectal route.

External administration techniques, apart from the chemical-physical composition of each type of mineral natural water, take advantage from hydromechanical and hydrothermal factors common to all hydrotherapy techniques. These include: i) bathing; (ii) showers; (iii) vapours; iv) massage showers; (v) pellets and (vi) several practices for application of water in benefit of the respiratory system. This means that the exposure to radon present in waters may effectively happen to bathers and workers as well, especially when their permanence in the treatment rooms is required.

\subsection{Concentration of radon in natural mineral water}

A summary of the overall values obtained for radon concentration in natural mineral waters is presented in Table 2.
Table 2. Summary of the results obtained for radon concentration in natural mineral water $(\mathrm{Bq} / \mathrm{L})$

\begin{tabular}{lcccc}
\hline \multirow{2}{*}{ Location } & S & Min. & Max. & Av. \\
\cline { 3 - 5 } & & \multicolumn{3}{c}{ Bq/L } \\
\hline Buvete (B) & 3 & 59 & 968 & 499 \\
ORL & 15 & 20 & 5195 & 718 \\
Thermal Pool (TP) & 8 & 0.1 & 953 & 284 \\
Hole & 24 & 32 & 6949 & 1149 \\
Spring (SP) & 3 & 23 & 478 & 251 \\
Vichy Shower (VS) & 2 & 45 & 2549 & 1297 \\
\hline Av. - average; S - number of samples & & &
\end{tabular}

A total of fifty-five water samples were analyzed for radon concentration. From this set of results, it is possible to observe a wide range of variation for radon levels: 0.1 - $6949 \mathrm{~Bq} / \mathrm{L}$, a geometric mean of $175 \mathrm{~Bq} / \mathrm{L}$ and an arithmetic mean of $842 \mathrm{~Bq} / \mathrm{L}$. The highest value was obtained in holes $(6949 \mathrm{~Bq} / \mathrm{L})$ and the lowest value in thermal pools $(0.1 \mathrm{~Bq} / \mathrm{L})$.

Thermal water used in ORL techniques presented more than $5000 \mathrm{~Bq} / \mathrm{L}$, slightly lower than the levels obtained for water samples taken directly from holes.

The obtained results, discriminated by thermal establishment, are presented in Table 3 (B - Buvete, TP - Thermal Pool, SP - Spring, VS - Vichy Shower). The identification (Table 1) is not linked to the presented data due to a confidentially agreement.

Table 3. Radon concentration in natural mineral water per location of sampling and thermal establishment $(\mathrm{Bq} / \mathrm{L})$

\begin{tabular}{cccccccc}
\hline & \multirow{2}{*}{ TE } & ORL & TP & \multicolumn{2}{c}{ Hole } & SP & VS \\
\cline { 3 - 8 } & & \multicolumn{7}{c}{ Bq/L } & 2 & & \\
\hline 1 & 968 & 976 & 6 & -- & -- & -- & -- \\
2 & 59 & 26 & -- & 41 & -- & -- & -- \\
3 & -- & 51 & 15 & 120 & -- & 86 & -- \\
4 & -- & 112 & -- & 759 & 380 & -- & -- \\
5 & -- & 5195 & & 6949 & 6775 & -- & -- \\
6 & -- & 1137 & 718 & 1373 & 1334 & -- & -- \\
7 & 471 & 102 & -- & 1446 & 423 & 478 & -- \\
8 & -- & 44 & -- & 57 & 53 & -- & -- \\
9 & -- & 75 & -- & 41 & -- & -- & 45 \\
10 & -- & 20 & 1 & 47 & 48 & -- & -- \\
11 & -- & 120 & 0.1 & 69 & -- & -- & -- \\
12 & -- & -- & -- & 199 & 452 & -- & -- \\
13 & -- & 127 & -- & 189 & -- & -- & -- \\
14 & -- & 2624 & 953 & 3090 & 3601 & -- & 2549 \\
15 & -- & 28 & 0.1 & 57 & -- & -- & -- \\
16 & -- & 63 & 10 & 47 & -- & -- & -- \\
17 & -- & -- & -- & 32 & -- & 23 & -- \\
\hline & & & & & & & 108
\end{tabular}


The results obtained for TE5 stand out by their magnitude, presenting values always above 5000 $\mathrm{Bq} / \mathrm{L}$.

The thermal establishment in which the lowest values of radon concentration in the water were obtained was in TE10 (1-48 Bq/L). However, this is in disagreement with the previous classification of these thermal waters as "radioactive water" [22] beside that fact that its spring is also located in a granitic area.

The locations where radon concentration in water is below the action level correspond to the thermal pools, with the exception of TE6 and TE14. A plausible explanation for the obtained concentration values may be due to the fact that as the water is treated there may be some stirring in this process and therefore the radon concentration is lower [23]. Another important contribution to the obtained values results from the fact that as the water is not replaced daily, there is a significant reduction in radon levels due to the decay into the solid progeny [24].

The obtained results were grouped into three categories, according to the radon concentration levels and both reference level and action level values: i) below the reference level $(100 \mathrm{~Bq} / \mathrm{L})$; ii) higher than the reference level but lower than the action level (100 $-1000 \mathrm{~Bq} / \mathrm{L}$ ); iii) higher than the action level (1000 $\mathrm{Bq} / \mathrm{L})$.

The concentration of radon in water from TE2, TE8, TE9, TE10, TE15, TE16 and TE17 did not exceed the EU reference level of $100 \mathrm{~Bq} / \mathrm{L}$. Accordingly, in previous literature [24], natural mineral waters from some of these thermal establishments (TE2, TE8, TE16 and TE17) were classified as non-radioactive.

However, in the same reference [25], the natural mineral waters from TE9, TE10 and TE15 are classified as highly radioactive (TE9) and radioactive (TE10 and TE15), although the results obtained in this study are below $100 \mathrm{~Bq} / \mathrm{L}$. In particular, for $\mathrm{TE} 4$ and TE13, natural mineral waters are classified as highly radioactive [24]. Nevertheless, the results obtained were between 100-1000 Bq/L. For other cases, TE7 and TE12, the water is classified as non-radioactive, contrary to the results obtained in several points where water samples from these two thermal establishments were taken and analyzed.

Regarding the results that exceeded the limit of action, $1000 \mathrm{~Bq} / \mathrm{L}$, only three thermal establishments stand out: TE5, TE6 and TE14. With the exception of TE5, the natural mineral waters from TE6 and TE14 are classified as strongly radioactive [26]. Moreover, although natural mineral water from ET5 is classified as non-radioactive water [24], it has been found out that the radon concentration in natural mineral water is quite high ( $>1000 \mathrm{~Bq} / \mathrm{L}$ ) and this is in a good agreement with its geologic setting (region with high outcropping of granites) [25].

In TE6 and TE14 radon concentration is below the action level (although above the reference level) only in the thermal pool, since for all other places radon concentration is above $1000 \mathrm{~Bq} / \mathrm{L}$.

\section{CONCLUSIONS}

The results of radon concentration in the natural mineral water revealed anomalous values, which are sometimes higher than normal, both at the reference level and at the action level. Approximately $50 \%$ of the results obtained for the radon concentration in natural mineral water are above the reference level recommended by the $\mathrm{EU}$, while $20 \%$ of the results exceeded the action level. The high values obtained in some cases are worrying and show the need for a more detailed and extensive study, both in space and time.

These results may also imply high concentrations of radon in indoor air, and hence occupational exposure to radon, since the natural mineral water will constitute a continuous source of this radionuclide. The extension of this exposure and the consequent risk will be much more relevant for workers than for bathers, as it will result in a shortterm impact for the latter, and in a long-term impact for workers who have longer and continuous exposure periods. In this way, this additional exposure may become extremely significant to this worker group and radon occupational exposure should, at least, be monitored.

\section{REFERENCES}

1. Radão - um gás radioativo de origem natural, Instituto Tecnológico e Nuclear, Lisboa, Portugal, 2010. (Radon - a radioactive gas of natural origin, Technological and Nuclear Institute, Lisbon, Portugal, 2010.)

Retrieved from: http://www.itn.pt/docum/relat/radao itn gas radao.pps; Retrieved on: Aug. 15, 2018

2. U. A. Tarim et al., "Evaluation of radon concentration in well and tap waters in Bursa, Turkey," Radiat. Prot. Dosim., vol. 150, no. 2, pp. 207 - 212, Jun. 2012.

DOI: $10.1093 / \mathrm{rpd} / \mathrm{ncr} 394$ PMid: 21990391

3. Radon Toxicity, Agency for Toxic Substances and Disease Registry, Atlanta (GA), USA, 2010.

Retrieved from: https://www.atsdr.cdc.gov/csem/rado n/radon.pdf;

Retrieved on: Aug. 15, 2018

4. Radiation Protection against Radon in Workplaces other than Mines, Safety Report Series No. 33, IAEA, Vienna, Austria, 2003.

Retrieved from: https://www-

pub.iaea.org/MTCD/Publications/PDF/Pub1168 web .pdf;

Retrieved on: Aug. 15, 2018

5. Lung Cancer Risk from Radon and Progeny and Statement on Radon, ICRP Publication 115, ICRP, Ottawa, Canada, 2010

Retrieved from: http://radon-and-

life.narod.ru/pub/ICRP 115.pdf;

Retrieved on: Aug. 15, 2018

6. K. Schmid, T. Kuwet, H. Drexler, "Radon in Indoor Spaces: An underestimated risk factor for lung cancer in environmental medicine," Dtsch. Arztebl. Int., vol. 107, no. 11, pp. 181 - 186, Mar. 2010.

DOI: 10.3238/arztebl.2010.0181

PMid: 20386676

PMCid: PMC2853156

7. Radon and cancer, Fact Sheet no. 291, WHO, Geneva, Switzerland, 2007. 
A.S. Silva \& M.L. Dinis, Radon concentration in natural mineral water, RAD Conf. Proc., vol. 3, 2018, 106-110

Retrieved from: http://www.who.int/en/newsroom/fact-sheets/detail/radon-and-health Retrieved on: Aug. 15, 2018

8. Effects of Ionizing Radiation, vol. 2, UNSCEAR, New York (NY), 2009.

Retrieved from: http://www.unscear.org/docs/publica tions/2006/UNSCEAR 2006 Report Vol.II.pdf; Retrieved on: Aug. 15, 2018

9. WHO handbook on Indoor Radon: A Public Health Perspective, WHO, Geneva, Switzerland, 2009. Retrieved from: http://apps.who.int/iris/bitstream/ha ndle/10665/44149/9789241547673 eng.pdf?sequenc

Retrieved on: Aug. 15, 2018

10. Health Risk of Radon, EPA, Washington (DC), USA, 2018.

Retrieved from: https://www.epa.gov/radon/healthrisk-radon;

Retrieved on: Aug. 28, 2018

11. A. M. S. Ferreira, "Radioactividade das Águas da Região Subterrâneas do Minho," Dissertação de Mestrado, Universidade do Minho, Escola de Ciências, Braga, Portugal, 2009. (A. M. S. Ferreira, "Water Radioactivity of Waters of the Subterranean Region of Minho," M.Sc. dissertation, University of Minho, School of Sciences, Braga, Portugal, 2009.)

12. A. S. Silva, M. L. Dinis, "Measurements of indoor radon and total gamma dose rate in Portuguese thermal spas," in Occupational Safety and Hygiene $I V$, P. Arezes, J. S. Baptista, M. Barroso, P. Carneiro, P. Cordeiro, N. Costa, R. Melo, A. S. Miguel, G. Perestrelo, Eds., London, UK: Taylor \& Francis Group, 2016. pp. $485-489$.

13. K. Q. Lao, Controlling indoor radon: measurement, mitigation, and prevention, New York (NY), USA: Van Nostrand Reinhold, 1990.

14. M. Al Zoughool, D. Krewski, "Health effects of radon: a review of the literature," Int. J. Radiat. Biol., vol. 85 , no. 1, pp. $57-69$, Jan. 2009.

DOI: $10.1080 / 09553000802635054$ PMid: 19205985

15. M. Erdogan, F. Ozdemir, N. Eren, "Measurements of radon concentration levels in thermal waters in the region of Konya, Turkey," Isotopes Environ. Health Stud., vol. 49, no. 4, pp. 567 - 574, 2013.

DOI:10.1080/10256016.2013.815182 PMid: 23937805

16. A. S. Silva, M. L. Dinis, A. J. S. C. Pereira, "Assessment of indoor radon levels in Portuguese thermal spas," Radioprotection, vol. 51, no. 4 pp. 249 - 254, Oct-Dec. 2016.

DOI: $10.1051 /$ radiopro/2016077.

17. Case studies in Environmental Medicine, ATSDR, Washington (DC), 2012

Retrieved from: https://www.atsdr.cdc.gov/csem/rado n/radon.pdf;

Retrieved on: Aug. 15, 2018

18. Standard Test Method for Radon in Drinking Water, ASTM D5072 - 09, 2009. DOI: $10.1520 /$ D5072-09

19. C. V. M. Gonçalves, A. J. S. C. Pereira, "Radionuclides in groundwater of the Serra do Buçaco region (Central Portugal)," in Proc. $X X X V$ Congress of the
International Association of Hydrogeologists, Lisbon, Portuga, 2007, p. 6.

20. Consumer's Guide to Radon Reduction: How to Fix Your Home, EPA 402/K-10/005, EPA, Washington (DC), USA, 2013

Retrieved from: https://www.epa.gov/sites/productio n/files/2016-

02/documents/2013 consumers guide to radon re duction.pdf;

Retrieved on: Aug. 18, 2018

21. The Council of the European Union. (Oct. 22, 2013) Directive 2013/51/EURATOM laying down requirements for the protection of the health of the general public with regard to radioactive substances in water intended for human consumption

Retrieved from: https://eur-lex.europa.eu/legalcontent/EN/TXT/PDF/?uri=CELEX:32013L0051\&fro $\underline{\mathrm{m}}=\mathrm{EN}$;

Retrieved on: Aug. 18, 2018

22. J.A. S. Cortez et al., Águas Minerais Naturais e de Nascente da Região Centro, Aveiro, Portugal: Mare Liberum, 2012. (J. A. S. Cortez et al., "Natural and Spring Mineral Waters of the Central Region," Aveiro, Portugal: Mare Liberum, 2012.)

23. P. Diegues, V. Martins, Águas termais riscos e benefícios para a saúde, Lisboa, Portugal: Auditório IPQ, 2010. (P. Diegues, V. Martins, Thermal waters risks and benefits for health, Lisbon, Portugal: Auditório IPQ, 2010.)

Retrieved from: https://www.dgs.pt/ficheiros-deupload-2/sa-aguas-termais-riscos-e-beneficios-paraa-saude final a.aspx; Retrieved on: Aug. 18, 2018

24. U. A. Tarim et al., "Evaluation of radon concentration in well and tap waters in Bursa, Turkey," Radiat. Prot. Dosim., vol. 150, no. 2, pp. 207 - 212, Jun. 2012.

DOI: $10.1093 / \mathrm{rpd} / \mathrm{ncr} 394$ PMid: 21990391

25. V. Radolić, B. Vuković, G. Smit, D. Stanić, J. Planinić, "Radon in the spas of Croatia," J. Environ. Radioact. vol. 83, no. 2, pp. $191-198,2005$.

DOI: 10.1016/j.jenvrad.2005.02.016 PMid: 15925434

26. A. Pereira, L. Neves, C. Gomes. J. Figueiredo, A. Vicente, "Concentração do gás radão em habitações da região de Castelo Branco (Portugal Central) e factores geológicos condicionantes," em Proc. VI Congresso Ibérico de Geoquímica e XV Semana de Geoquímica, Vila Real, Portugal, 2007. (A. Pereira, L. Neves, C. Gomes, J. Figueiredo, A. Vicente, "Gas concentration in the habitation region of Castelo Branco (Central Portugal) and geological conditioning factors," in Proc. VI Iberian Congress of Geochemistry and XV Geochemistry Week, Vila Real, Portugal, 2007.)

Retrieved form: https://dadospdf.com/queue/concent raoes-do-gas-radao-em-habitaoes-da-regiao-decastelo-branco-portugal-central-e-factores-geologicoscondicionantes-

5a44ce58b7d7bc891f84fb71 pdf?queue id=-1;

Retrieved on: Aug. 18, 2018 